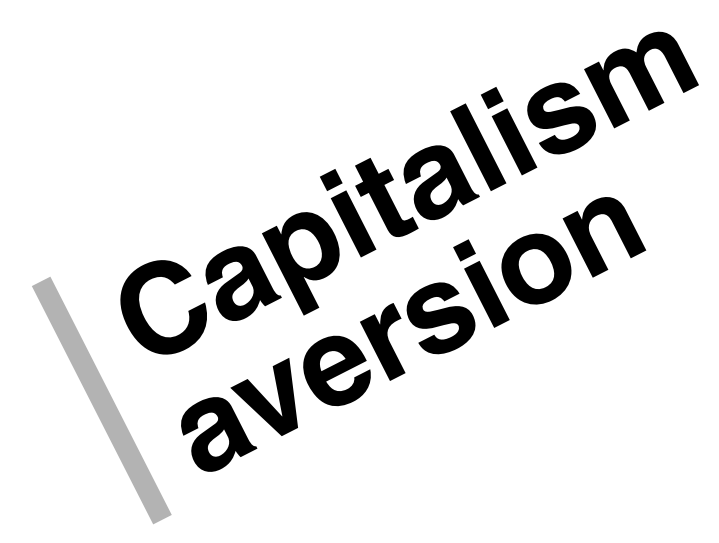

\title{
SUMMARY
}

There are two non-mutually exclusive theories of individual variations in procapitalism opinions. The first theory viewes pro-capitalism opinions as self-serving: Individuals are opposed to market forces when they threaten their economic rents. The second theory views differences in such opinions as reflecting genuine disagreement on the efficiency of various economic systems. Using individual data, we investigate the validity of both theories, focusing on attitudes toward private ownership, private profit and competition. We find evidence that the first theory explains some of the variations in attitudes. However, consistent with the second theory, we also find evidence of individual learning about the comparative virtues of economic systems. The learning is slow, home-biased and path-dependent. Long-run cultural and historical determinants of pro-market attitudes, such as religion and legal origins, explain more than $40 \%$ of the cross-country variations in capitalism aversion. Last, we provide tentative evidence that at the country level, pro-market opinions affect the nature of economic institutions. Our results suggest that the feasibility of economic reform does not depend solely on its impact on the distribution of rents; ideological a-prioris are likely to be important as well.

- Augustin Landier, David Thesmar and Mathias Thoenig 


\section{Investigating capitalism aversion}

\section{Augustin Landier, David Thesmar and Mathias Thoenig}

New York University - Stern School of Business; HEC Paris; University of Geneva and Paris School of Economics

\section{INTRODUCTION}

Since at least Adam Smith, a key message of classical economics is that the appetite for profits of entrepreneurs competing on a free market is a powerful tool for reaching an efficient allocation of resources in the economy. Although very few economists would argue that business does not require any regulation, a consensus exists that, in many instances, competition and the quest for profit can be harnessed for the common good. Yet, people's attitudes toward the virtues of free markets vary widely across countries. According to the World Value Survey (WVS), only 22.1\% of the French believe that 'the owners should run their business and appoint their managers', while as much as $58.7 \%$ of the Americans would agree with this statement. These differences are surprising for countries with similar levels of economic development and not so different political institutions. We believe that the persistence of such a dispersion in pro-market attitudes calls for a thorough study of its determinants. In this paper, we investigate why some countries are more capitalism averse than others.

We test two alternative theories of opinion formation: the 'self interest' hypothesis, whereby agents express attitudes that are self-serving vis-à-vis their individual vested

This paper was prepared for the October Panel Meeting of Economic Policy in Lisbon (October 2007).

The Managing Editor in charge of this paper was Jan van Ours. 
interests, and the 'slow learning' hypothesis, whereby different opinions reflect genuine disagreement about the relative aggregate effects of economic systems. According to the first theory, agents favour reforms that maximize their individual wealth given their current status in the system in place; if their status changed, they would change their view on the desirability of reforms accordingly. In the second theory, an agent's opinion reflects foremost ideological views on the aggregate welfare which agents would not instantaneously revise if their status in society was changed. In this case, beliefs are likely to be path-dependent and shaped by national history: This does not require that agents be irrational, but simply that their information set is limited and/or that learning about economics is costly.

These two alternative theories have been formulated in Acemoglu (2003) and more informally in Robinson (1998). Acemoglu (2003) describes them as the two alternative explanations for why a 'Political Coase Theorem' might not hold empirically. In his paper, Acemoglu explains that there are only two types of explanations for why inefficient economic systems are adopted by societies: Either vested interests combined with incomplete contracts prevent the reach of a Pareto-efficient outcome (theory 1) or these different choices reflect genuine disagreement on what system is efficient (theory 2).

Distinguishing between these two views is, we believe, crucial for the optimization of economic reform packages: If a pro-market reform faces hostility for the first reason, the crucial task for a reformist government is to make sure that a large enough constituency benefits from the reform, for example by coupling it with a redistributive package that makes sure individuals get compensated for the rents destroyed by the reform (as suggested by Delpla and Wyplosz, 2007). In other words, appropriate and credible transfer programmes would make the 'Political Coase Theorem' hold in this economy (Acemoglu, 2003). However, if a reform faces hostility for the second reason, the task of the reformist government is to use pedagogy and to make sure that information about the positive effect of similar reforms in other countries are available to the public in an accessible and credible form. A remark in a conference discussion by development economist Kausjik Basu (1992) illustrates concretely why distinguishing both theories is important for political reformers:

Attempts to remove such a subsidy [to fertilizers in India] have turned out to be politically impossible and the majority of those opposing the removal do so not because they are themselves adversely affected by it (as public choice theory suggests) but because they believe that removing the subsidy will be bad for the economy.

To test these two competing hypotheses, we use individual level data from the WVS, and focus on attitudes towards competition and private profits. First, we find some evidence that opinions expressed by individuals on different economic systems are 'self serving' (i.e. reflect the selfish interest of these individuals), which is the assumption prevailing in most political economy models. Using an approach akin to the difference in difference methodology used in experimental setting, we find that 
agents with more financial wealth tend to express more support for 'private profit'. However, though significant, these effects are small in magnitude and leave most of the dispersion of beliefs unexplained.

We then explore the second theory (the 'slow learning' view) and find that learning about the comparative virtues of economic system is slow, and largely affected by history. We find that generations that have been exposed to massive doses of planning tend to underestimate the benefits of free market. Using the post-communist transition as a natural experiment, we find differences that are sizeable, quantitatively. We finally find that citizens tend to attribute economic outcomes to the system in place in their country: faced with a positive growth shock, pro-market opinions become relatively stronger in countries that have pro-market institutions.

Such evidence of slow learning suggests that, in the cross-section of countries, opinions are unlikely to converge fast and therefore are determined by long-run history. Yet, it says little about why such differences emerged in the first place. We therefore investigate cultural and historical determinants of the cross-section of pro-capitalism attitudes. Building on previous literature, we focus on trust, religion and legal origins. Trust is uncorrelated with opinions, while religion and legal origins explain more than $40 \%$ of the cross country variation in attitudes.

Finally we discuss some implications for economic policy by investigating whether pro-market attitudes (at least in democracies) matter for the feasibility of economic reforms. We provide some tentative evidence that aggregate economic opinions indeed correlate strongly with the type of economic institutions adopted by each country.

There is an emerging literature which seeks to understand opinions about the relative merits of economic systems. Our paper contributes to it by shifting the focus on attitudes toward competition and private profits. Borne by a large political economy literature, recent academic work has mostly studied attitudes toward redistribution ${ }^{1}$ and towards free trade. ${ }^{2}$ In a recent book, Alesina et al. (2001) have asked why the welfare state is larger in Europe than in the United States. Surprisingly - at least for economists - they find very little support for traditional, political economy based, explanations. Given the higher volatility and inequality of the US economy, the United States should redistribute more, not less than Europe. Thus, the authors move away from a pure economic explanation and go as far as suggesting that some specificities of US history - a large country, ethnic heterogeneity, the early emancipation of the Supreme Court - have endowed modern American citizens with persistent anti-redistributive beliefs.

Very few papers have sought to understand the attitudes toward competition and for-profit motive, the two dimensions that we focus on in the present article. Di Tella et al. (2007) show that squatters in Buenos Aires who were randomly allocated the

\footnotetext{
${ }^{1}$ See also Alesina and Laferrara (2000), Luttmer (2001), Alesina et al. (2001) and Alesina and Fuchs (2007).

2 See for instance O'Rourke and Sinott (2001a) and Mayda and Rodrik (2005) on free trade; Mayda (2006) and O'Rourke and Sinott (2006) on immigration.
} 
ownership of their homes adopted more materialistic and individualistic beliefs. Di Tella and Mc Gulloch (2004) argue that people in poor countries tend not to elect pro-capitalism parties because they perceive such platforms as benefiting mostly to rich capitalists. Closer to us is Guiso et al. (2003b), who look at the correlation between religious beliefs and several economic attitudes - in particular vis-à-vis competition but also inequality, thrift etc. A main difference with our paper is that we explore a wider range of determinants, such as political economy ones, but also behavioral or historical ones, that they do not investigate in their study.

This paper is structured as follows. Section 2 exposes our conceptual background. Section 3 describes the dataset we use. In Section 4 we test the 'self-interest' view, whereby individual express self-serving opinions about economic systems. In Section 5, we test the 'slow learning' hypothesis, which posits that learning about the relative merits of competition and private property of firms is imperfect and highly path dependent. Section 6 analyses some cross-country determinants of pro-capitalism attitudes which relate to culture and past history. Section 7 explores whether promarket opinions affect the feasibility of economic reforms. Section 8 concludes.

\section{WHAT DETERMINES PRO-CAPITALISM ATTITUDES? TWO HYPOTHESES}

Following Acemoglu (2003) and Robinson (1998) we distinguish two types of determinants of attitudes about private ownership of firms, which arise from two distinct - yet non-mutually exclusive - theories of the formation of economic opinions. One first theory contends that each individual supports the system that maximizes his or her utility given his/her initial endowment in physical human and social capital. This assumption is at the root of most political economy models, who assume that agents vote in line with their interests. We label this view the 'self interest hypothesis'.

One other possibility is that agents selflessly form beliefs about what is optimal from the society viewpoint. In this case attitudes would not reflect redistributive concerns but rather differences in opinions about the aggregate consequences of different economic systems. To take an example, some individuals might believe that 'free markets' maximize total economic surplus while others believe that markets are erratic, prone to bubbles, and that a large level of government intervention is required to 'rationalize' the economy. If such beliefs were formed rationally, they would be the same all over the world, so it must be the case that the process of belief formation over-weights local experience and history, that beliefs are somewhat 'sticky'. We will thus refer to such theory as the 'slow learning hypothesis'.

\subsection{The main econometric framework}

None of these views is easy to test with aggregate data, mostly because of endogeneity concerns. Indeed, if economic institutions adopted by a country result from the population's average belief, we will not be able to test how economic rents determine 
beliefs without looking at individuals with different characteristics within countries. This is why we will use individual level data on attitudes from the WVS.

Fortunately, for reasons that will become clearer below, both views give a central role to institutions. Under the 'self-interest hypothesis', economic institutions shape the redistributive circuit, and determine individual support for a given policy. Under the 'slow learning hypothesis', institutions are the legacy of history and collective experience, and as a result, impact current beliefs.

Both types of theories predict that the link between individual attitudes and individual characteristics (such as age, education) will be different depending on the institutional background. Thus, the attitude att $i_{c t}$ of individual $i$, living in country $c$, at date $t$, should satisfy the following type of equation:

att $_{i c t}=\alpha_{c}+\delta_{t}+\beta \cdot C_{i t} \times Z_{c}+\gamma \cdot X_{i t}+\varepsilon_{i c t}$

where $\alpha_{c}$ is a country fixed effect, $\delta_{t}$ a temporal effect and $\varepsilon_{i c t}$ an error term. $X_{i t}$ represents various individual characteristics (such as age, gender, education etc.). $C_{i t}$ is one particular characteristic (say, age), whose impact on attitude is affected by the institutional background. $Z_{c}$ is the dimension of country level institutions which is supposed to matter.

As we will see below, 'self interest' and 'slow learning' theories of belief formation have specific predictions on the sign of $\beta$ (for different variables $C_{i t}$ and $Z_{c}$ ). Because we look at interaction terms, this approach is akin to difference-in-difference estimators used to evaluate the effect of natural experiments. To see this analogy more intuitively, think of two countries, A and B. In country A, institutions are such that, say, left-handed people (individual characteristic $C_{i t}$ ) have access to high-wage government jobs (countryspecific institution $Z_{\mathrm{A}}$ ), while in country $\mathrm{B}$, such privileges do not exist. The interaction term $\beta$ measures whether, compared to the right-handed, left-handed people are more 'pro-government' in country A than in country B (as the self-serving view would predict). In the language of 'diff-in-diff' estimation, the 'treated group' is the lefthanded, the 'control-group' is the right-handed, and we compare differences in the attitudes of both groups after treatment (country A) and without treatment (country B) which isolates the effect of the treatment (the institutional difference between both countries) on individual attitudes. The advantage of this approach is that it provides an identification that is still valid even if: (i) the left-handed were intrinsically more pro-government than the right-handed; or (ii) all citizens of one country were on average more pro-government than in the other for some other reason than the treatment; or (iii) there were a larger fraction of left-handed in one country versus the other.

Using Equation (1) to test the predictions of both theories is therefore a powerful test: It alleviates endogeneity concerns by using individual level data, but also allows controlling for country specific effects. Thus, our tests do not rest on interpreting in a causal way the correlation between country characteristics and typical attitudes.

We now turn to the exact content that both 'self interest' and 'slow learning' hypotheses give to the variables of Equation (1). 


\subsection{The 'self-interest hypothesis'}

The 'self interest hypothesis' has provided the underpinnings of most existing studies on economic attitudes. For instance, there has been a long tradition, since at least Metzler and Richard (1981), in the political economy literature, arguing that individual demand for redistribution depends on one's income compared to the average income (what one would have if aggregate income was shared with perfect equality). Poorer than average people support redistribution, and more unequal societies are more likely to vote for redistribution. This theory, however, does poorly at explaining why the United States does not have a European-like welfare state (Alesina et al., 2001).

Studies of attitudes toward free trade are much more consistent with the selfinterest hypothesis. Mayda and Rodrik (2005) find that, in developed countries, it is unskilled workers, and those who are working for highly exposed industries (whose sector specific human capital is the most at risk), who are the least supportive of free trade. This is consistent with the redistributive effects of free trade. In her study of attitudes toward immigration, Mayda (2006) finds that people with a high level of education or with a high level of income are the most favourable to (unskilled) immigration. Such evidence is consistent with what a standard Hecksher-Ohlin model would predict, where the rich and the skilled benefit more from globalization.

Hereafter we explore pro-market attitudes, that is, opinions about whether firms should indeed compete and seek to maximize profits. In political economy theory, two recent papers (Pagano and Volpin, 2005; Perrotti and Von Thadden, 2006) suggest that investor protection is the result of a political equilibrium, where investors want more protection, while workers want less. Both papers have the built-in feature that support for investor protection is an increasing function of the ratio of financial wealth to human wealth (see also, in the growth literature, Alesina and Rodrik, 1994). Because they derive (relatively) more returns from capital than from labour, citizens with such a high ratio are more likely to defend policies that guarantee returns to capital.

Similarly, we expect a positive relationship, at the individual level, between the amount of financial wealth and support for profit maximizing firms. First as, obviously, not maximizing profit makes firms' investors - in particular equity holders - poorer. Secondly, there is indirect evidence that non-profit maximizing firms tend to make employees richer, which increases human wealth. A first very obvious testing ground for such hypothesis is to look at privatizations. Investigating network industries, Azmat et al. (2007) find that labour's share decreases with privatization, which indicates that state ownership biased hiring decisions towards more employment. But such effects also show in private firms. For instance, there is a large literature in finance exploring the 'empire building' hypothesis, that is, the fact that firms with weak investors (dispersed shareholders, poor corporate governance) tend to over-invest and over-hire to satisfy the hubris of their CEOs. There is evidence of such behaviour in studies of the hostile takeovers and LBOs of the 1980s US (Kaplan, 1989), but the 
effect on employment is apparently small, if not negligible. Another possibility is that firms under pressure from their owners tend to behave in a more volatile way, which transfers risk to employees (Bertrand and Mullainathan, 2003).

Unfortunately, the WVS does not have data on financial wealth, so that it is not possible to test this prediction directly. Instead, we will claim that the difference in financial wealth between younger and older individuals is stronger in countries where citizens have to save more for retirement. In countries with a full Pay-As-You-Go system, individuals have to save very little over their life cycle to complement their retirement income. As a result, in such countries, there is little difference in financial wealth between younger and older workers, other things equal. In countries where pensions are fully funded, older workers nearing the retirement age tend to own, either directly or indirectly, more financial assets, than younger generations. We will thus focus on the interaction between age and retirement systems, and ask the data if the sensitivity of pro-capitalism attitude to age is increasing in the funding of the pension system. As discussed previously this approach where we focus on an interaction term is analogous to the difference-in-difference methodology used in experimental settings.

As a robustness check we also look at de facto financial development as a measure of availability - affordability - of financial assets for saving; in that case we are interested in the interaction term between age and country-level degree of financial development. The intuition of these specifications is that de facto financial development is an indirect measure of the costs to save (transaction costs, liquidity, competitiveness of the money management and the banking industry). Thus, given the higher propensity to save of higher income individuals, the differential wealth across income categories should be higher when the financial industry is more developed. The young-old differential should also be larger, given that economic agents save more when costs are lower.

The self-interest view also makes predictions about attitudes toward competition, albeit less sharp ones. In their study of network industries, Azmat et al. (2007) find that the share of output that is appropriated by suppliers of capital - one minus labour's share - tends to decline when measures competition increases. This fact is perfectly consistent with standard economic intuition. An increase in competition tends to wipe out profits margins: as a result, support for competition is lower for agents with more financial wealth (this is, for instance, the assumption behind Rajan and Zingales' (2003b) analysis of the political economy of competition). Yet, within a more elaborate model, it could be argued that forces of competition also amplify firm level uncertainty: this particular effect is harmless for shareholders, who can diversify, but it may hurt workers who can only hold one job at once (Thesmar and Thoenig, 2006). ${ }^{3}$ Unless this second effect dominates the first one, however, we expect support for competition to be a decreasing function of the financial wealth to human wealth ratio.

\footnotetext{
${ }^{3}$ One alternative could be that competition is interpreted in the survey as 'international competition' or 'globalization' (as in O'Rourke and Williamson, 1999). In this case, it should come as no surprise that owners of capital, in capital rich countries, favour 'competition', as it allows them to rent their capital in the world. In our dataset, however, there are a priori as many capital rich, as capital poor countries. As a result, this mechanism should not generate any systematic bias in our methodology.
} 


\subsection{The 'slow learning hypothesis'}

For all its intuitive appeal, the 'self-interest view' cannot fully explain the dispersion in pro-capitalism tendencies across countries. Indeed, in all countries the representative household has too little financial wealth. A recent study of the US wealth distribution (Kennickel, 2006) shows that the net worth of the median US household is around $\$ 93000$ in 2004. This figure is an overestimate of net financial wealth as it also includes real estate. Moreover, the representative household is unlikely to own stocks. Guiso et al. (2003a) estimate that only $48 \%$ of US households own stocks directly or indirectly. This figure drops to 34\% for the United Kingdom, 23\% for France and $15 \%$ for Italy. This makes it unlikely that the median voter will just support profit maximization by firms because it boosts the return of its portfolio, given that his human wealth (as well as his real estate wealth) is well above his financial wealth. Yet, in the WVS, $57 \%$ of the US respondents agree with the statement that the 'owners should appoint the management'. According to the General Social Survey (again conducted in the United States, where equity ownership is the most diffused), more than $70 \%$ of the respondents who declare working for someone else agree with the fact that 'management should only care about profits'. Thus, the diffusion of equity ownership cannot explain alone why the citizens of this country lend their support to free markets more than in other countries.

Beyond self-serving rent-maximization, opinions also reflect beliefs that are only imperfectly updated in the face of new evidence. Thus, individuals and public opinion are 'slow learners'. One first line of explanation is that individuals do not optimally use the information that is available to them (i.e. they do not update their beliefs using Bayes' rule), and lean too much on their a-priori. For instance, the cognitive psychology literature has gathered ample experimental evidence that agents overweight new information congruent with their priors. This is the so-called 'confirmatory bias' (for an economic model, see Rabin and Shrag, 1999). An important consequence of the confirmatory bias is that, even when faced with a large flow of similar information, the beliefs of agents might not converge. At the cross-country level, the difference in public attitudes toward capitalism can thus persist for a very long time.

But learning does not have to be irrational to be slow. It can follow from bounded rationality constraints such as costly information acquisition. Even if agents were to use information optimally, learning about the actual impact of economic reforms is difficult, because such events are rare, and the link between reforms and performance very noisy. This is especially true when most agents only have access to national history to forge their beliefs. Given the paucity of information, and the complexity of the economic model to be estimated, even if agents were to use information optimally (were Bayesian), national opinions may never converge. This point is modelled theoretically by Piketty (1995) in the context of beliefs about redistribution. Piketty argues that, while the standard 'political economy view' of redistributive politics would suggest that low income people should vote in favour of redistribution, it appears that 
voting patterns are only weakly explained by income differentials. Many working-class persons support right-wing, anti-redistributive policies on the ground that they induce too many distortions, in spite of the fact that it would be in their interest to do so. As it turns out, parental income explains voting decisions as much as one's personal income, which suggests that people start with the beliefs of their parents and update them using their own experience. As Piketty points out, it is difficult to learn much about the costs and benefits of redistribution purely based on one's family experience, so that, even if agents are Bayesian they may never converge to the right beliefs. Moreover, as explained by Glaeser (2006), agents have 'weak incentives to learn the truth' about the optimality of various economic policies as their individual votes are unlikely to be pivotal. In turn, this leaves room for influence groups such as political lobbies to 'scramble' information at their own advantage.

Whether one favours the behavioural view or Piketty's Bayesian model, the slow learning hypothesis for cross-country dispersion in opinions rests on two important assumptions. The first assumption is that initial priors matter a great deal in shaping future opinions. The second assumption is that individuals overweight their own experience; they do not exploit enough information about foreign experiences, and rely too much on domestic, idiosyncratic, experiences to update their priors.

One consequence of this is that young generations, when they experience a radically different economic context than older generations, should have different opinions. Thus we will focus our analysis on the generational differences in former socialist countries. We estimate whether the difference in pro-market attitudes between individuals who were born before and after 1970 is larger in former socialist countries than in other comparable countries. The econometric specification will be the one of Equation (1) and will allow controlling for country fixed effects.

Then we ask whether learning is home biased. If it is the case, agents should update their beliefs by overweighting their home country economic performance rather than by comparing systematically the worldwide relative performance of free markets versus less free market economies. More specifically, we will estimate the correlation between pro-capitalism attitudes and economic growth. First, as an indirect test of the 'confirmatory bias' hypothesis, we expect that pro-capitalism attitudes overreact to positive growth shocks in countries that have the most market friendly institutions. Secondly, as a test of the domestic bias in learning, we will compare the relative force of domestic and foreign experiences in the formation of opinions by estimating the reaction of domestic attitudes when other market friendly economies in the world experience a higher growth.

\section{DESCRIPTION OF THE DATA}

\subsection{Datasets}

We use two types of datasets: Household-level survey for opinions and attitudes; Country-level surveys for economic and institutional data. 
On the opinion side, our main source is the 'integrated' dataset of the WVS, which has collected answers about various attitudes across countries for the past 25 years. This 'integrated' dataset is a repeated cross-section that comes in four waves (1981-1984, 1989-1993, 1994-1999 and 2000-2004). For each wave, representative samples of households from different countries were surveyed, using a harmonized questionnaire. Country coverage increases from one wave to the next. In the first wave, 21 countries were surveyed. The second, third and fourth waves have 82 countries. Sample size varies across countries. For instance, in the first wave, the US had 2325 data points, while Malta only 467. These outliers aside, sample size is between 1000 and 1400 for the remaining countries. In the fourth wave, there is a little more dispersion: most countries have between 1000 and 2000 data points, the Ukraine has 2811.

In addition to attitudes (on economics, but also on marriage, religion etc.), the WVS also provides us with basic socio demographics: age, gender, education, income (three categories), job held, and employment status. These variables will be used both as controls and variable of interest.

We also use economic data, available at the country level. National accounts are retrieved from the Penn World Table which covers the period from 1950 to 2004. We also use two measures of financial development. The first one is the standard de facto measure constructed as the sum of stock market capitalization to GDP and private credit to GDP (from Beck and Levine, 2004). The second measure is a de jure measure of financial development ranking from 0 to 3 (from Kaminsky and Schmukler, 2008). We also use the extent of pension funding measured as the ratio of pension funds + life insurance liabilities to GDP in 2003 (source: OECD). Finally we use an index of product market deregulation (defined as the opposite of the index of regulatory barriers to entry taken from Djankov et al., 2002).

\subsection{Three measures of pro-capitalism beliefs}

This paper investigates the determinants of pro capitalism attitudes. To do so, we base our analysis on three variables constructed from the WVS, which we will use as our left-hand side variables:

- Private ownership: Respondents were asked to grade the merits of private ownership of business and industry on a scale from 1 to 10 , from 'Private ownership of business and industry should be increased' (1) to 'Government ownership of business and industry should be increased' (10). We construct a dummy variable equal to 1 if the respondent selects a grade below 5 .

- Owner control: This question is about which stakeholder should have effective control of firms. The exact phrasing of the question is 'There is a lot of discussion about how business and industry should be managed. Which of these four statements comes closest to your opinion? (1) The owners should run their business or appoint the managers, (2) The owners and the employees should participate 
Table 1. Attitudes towards corporate profits for various countries

\begin{tabular}{lccc}
\hline \hline & $\begin{array}{c}\text { Owner should } \\
\text { control the firm }\end{array}$ & $\begin{array}{c}\text { Competition } \\
\text { is good }\end{array}$ & $\begin{array}{c}\text { Private } \\
\text { ownership }\end{array}$ \\
\hline New Zealand & 64.1 & 56.5 & 73.8 \\
United States & 57.7 & 62.8 & 86.3 \\
Canada & 53.8 & 59.5 & 81.2 \\
Australia & 50.3 & 63.9 & 81.8 \\
Austria & 49.8 & 62.5 & 87.2 \\
Switzerland & 46.9 & 64.8 & 84.9 \\
United Kingdom & 46.0 & 47.3 & 67.2 \\
Iceland & 45.2 & 72.5 & 83.3 \\
Denmark & 44.3 & 47.8 & 83.6 \\
Belgium & 44.0 & 41.8 & 78.9 \\
Singapore & 42.9 & 57.6 & 56.8 \\
Japan & 40.4 & 34.2 & 70.3 \\
Finland & 37.8 & 48.6 & 81.9 \\
Germany & 36.5 & 58.1 & 77.8 \\
Norway & 34.8 & 58.4 & 77.3 \\
Netherlands & 33.6 & 33.1 & 76.5 \\
Sweden & 32.5 & 60.1 & 80.8 \\
France & 22.0 & 40.5 & \\
\hline \hline
\end{tabular}

Note: Figures represent country averages for each of the three attitudes (in \%).

Source: World Value Survey.

in the selection of managers, (3) The government should be the owner and appoint the managers or (4) The employees should own the business and should elect the managers.' We construct a dummy equal to 1 when the respondent selects the first statement.

- Competition is good: We use the following question from the WVS: 'How would you place your views on this scale: Competition is good, it stimulates people to work hard and develop new ideas (1) or competition is harmful. It brings the worst out of people (10)'. We construct a dummy equal to 1 when answers are less than or equal to 7 .

The reason we use these three different proxies is twofold: First, we want to document the robustness of our results to the choice of different questions from the WVS. Second, because individuals benefiting from free financial markets are not necessarily those benefiting from competition, using these different proxies enables us to distinguish between the two theories we test.

The data show a large variation in cross country attitudes toward free markets. Table 1 displays mean variables for all three attitudes within the 18 richest countries in our sample - in terms of PPP GDP per capita.

Table Al in the Appendix reports the sample statistics for these attitudes, as well as for various socio-demographic characteristics that will serve both as controls and variables of interest. Approximately $40 \%$ of the respondents have average income and average education. Their average age is 41 years old. Women account for $52 \%$ 
of the sample; $63 \%$ of the respondents think that private ownership of business should be increased, $37 \%$ of them prefer to leave firm control to owners, rather than to the state, the employees, or joint representatives of employees and owners.

Beyond sample means, it is interesting to see how the three measures of procapitalism attitudes correlate with each other. The propensity to support private ownership is well correlated with the 'owner control' (0.14) and 'competition' (0.14). These correlation coefficients are surprisingly large, given the large number of observations. More surprisingly perhaps, 'owner control' and 'competition' are also positively correlated (0.08), albeit to a lesser extent.

\section{TESTING THE 'SELF-INTEREST HYPOTHESIS'}

In this section, we test the 'self-interest hypothesis', whereby attitudes toward private profit reflect respondents' own economic interests. As discussed in Section 1, testing the 'self-interest hypothesis' suggests running a logistic regression as described in Equation (1) where the variable of interest $C_{i t} \times Z_{c}$ corresponds to the interaction between individual age and the extent of pension funding at the country level. We expect the coefficient of this variable to be positive, as the difference in financial wealth between old and young people is likely to be larger in countries where pensions are funded. The first advantage of this identification strategy is that it uses inter individual variability to test the 'self interest hypothesis'. It does not rely on crosscountry correlations between, say, pension and average pro-capitalism attitudes, that would be difficult to interpret causally. The second advantage of this approach is that it allows controlling for individual characteristics, such as income, education or age, which may be argued to affect support for private profits.

As it turns out, we estimate 12 different versions of Equation (1), whose results are reported in Table 2. All specifications include country fixed effects, year dummies and the socio-demographic characteristics provided by the WVS: age, gender, income and education.

In Table 2, columns 1-4 take 'private ownership' as a dependent variable, columns 5-8 take 'owner control'; columns 9-12 take 'competition is good'. In columns 1, 5 and 9, our main variable of interest is the interaction between age and the extent of pension funds while in columns 3, 7 and 11, it is the interaction between income and the extent of pension funds. Specifications 2, 4, 6, 8, 10 and 12 replicate columns 1, 3, 5, 7, 9, 11 with a measure of financial development instead of pension funding. As discussed in Section 1, the 'self-interest' theory predicts all those interaction terms to be positive.

In 9 cases out of 12 specifications, results are statistically significant. In countries where pensions are funded, in financially developed countries, the old are much more likely to be supporters of free markets than the young. Higher income individuals are more likely to support profit-making behaviour in financially developed countries, comparatively to poorer agents. On the contrary, the high income-low income gap is lower when agents have to save for retirement. Results relating to attitudes toward 
Table 2. Pro-capitalism and financial wealth

\begin{tabular}{|c|c|c|c|c|c|c|c|c|c|c|c|c|}
\hline \multirow[t]{2}{*}{ Dependent variable } & \multicolumn{4}{|c|}{ Opinion on 'private ownership' } & \multicolumn{4}{|c|}{ Opinion on 'owner control' } & \multicolumn{4}{|c|}{ Opinion on 'competition is good' } \\
\hline & 1 & 2 & 3 & 4 & 5 & 6 & 7 & 8 & 9 & 10 & 11 & 12 \\
\hline (Pensions Fund $) \times($ age $)$ & $\begin{array}{c}0.018 * * \\
{[0.007]}\end{array}$ & & & & $\begin{array}{l}0.036 * * * \\
{[0.006]}\end{array}$ & & & & $\begin{array}{l}0.018^{* * * *} \\
{[0.006]}\end{array}$ & & & \\
\hline$($ Financial Dev. $) \times($ age $)$ & & $\begin{array}{l}0.005^{\text {***** }} \\
{[0.001]}\end{array}$ & & & & $\begin{array}{l}0.008^{* * * *} \\
{[0.001]}\end{array}$ & & & & $\begin{array}{l}0.003 * * * \\
{[0.001]}\end{array}$ & & \\
\hline$($ Pensions Fund $) \times($ income $)$ & & & $\begin{array}{c}-0.077 \\
{[0.256]}\end{array}$ & & & & $\begin{array}{c}-0.224 \\
{[0.214]}\end{array}$ & & & & $\begin{array}{l}0.650 * * * \\
{[0.205]}\end{array}$ & \\
\hline (Financ. Dev. $) \times($ income $)$ & & & & $\begin{array}{l}0.056 * * * \\
{[0.020]}\end{array}$ & & & & $\begin{array}{l}0.090 * * * \\
{[0.022]}\end{array}$ & & & & $\begin{array}{c}0.028 \\
{[0.019]}\end{array}$ \\
\hline Observations & 37810 & 10060 & 37810 & 100600 & 25204 & 82946 & 25204 & 82946 & 42954 & 95765 & 42954 & 95765 \\
\hline
\end{tabular}

Notes: Logit estimates. All specifications include year fixed effects, country fixed effects and socio-demographic controls (age, income, education and gender - unreported coefficients). Income is a dummy equal to 1 if individual income is reported as high (as opposed to medium or low). Columns $1-4$ use 'private ownership' as the dependent variable. Columns 5-8 use 'Owner control' as the dependent variable. Columns 9-12 use 'Competition is good' as the dependent variable. Standard errors are in parentheses. * Significant at $10 \%$; ** significant at $5 \%$; *** significant at $1 \%$.

Sources: WVS for attitudes and socio-demographics (see text), OECD (2003) for pension funds (2003 ratio of life insurance and pension funds liabilities to GDP), Beck and Levine (2004) for financial development (current year ratio of private credit and stock market capitalization to GDP). 
competition (columns 9-12) show that higher net wealth individuals are more, not less, likely to support competition. This empirical finding goes against the simple economic intuition that competition tends to increase labour's share in total GDP, and therefore, improves the welfare of workers more than the welfare of capitalists. As suggested in our theoretical discussion above, one possibility is that competition is associated with more turbulence on the labour market that capitalists are protected from.

Quantitatively, the effects are small. Let us consider the difference in probability to support private profits of agents aged 30 and agents aged 50 (this corresponds to approximately one standard deviation of age). Taking estimates of column 1, this implies that, when the ratio of contractual savings (pension funds plus life insurance) increases by $10 \%$ of GDP (again, one sample standard deviation), differential support for private ownership increases by 0.6 percentage points (compared to a sample mean for the dependent variable of $63 \%$ ). The old-young gap widens significantly, but to a small extent, when pensions become more likely to be funded. Quantitatively, the effect is twice as large for the question on owner control. Thus, the 'self-interest view' holds, but it has a small predictive power over the dispersion of pro-capitalism attitudes.

\section{TESTING THE 'SLOW LEARNING HYPOTHESIS’}

To explain the persistence in cross-country differences in pro-capitalism attitudes, the 'slow learning' hypothesis rests on two assumptions: first, agents learn slowly, and second, they overweight the economic history of their country. We will test these assumptions in turn. Put together, these two assumptions explain why (sincere) differences opinions may survive in the long run; but they do not explain the cross-section variation in country level opinions. This is why we will then investigate the explanatory power of long-run historical determinants of these opinions in Section 6.

\subsection{Slow learning: evidence from former socialist countries}

To look at learning, it is natural to ask if the young believe differently from the old. A reason for this is that, at birth and throughout their education, both generations have lived through different experiences. One example of very radical change in exposition of the young to capitalist institutions is the transition away from communism of eastern European countries. In these countries, we thus compare pro-capitalism attitudes held by younger generations to attitudes of generations that were already adults when the Berlin Wall fell. This can be done by running the following logistic regressions on WVS data, for individual $i$, living in country $c$, in wave $t$ :

att $_{i c t}=\alpha_{c}+\delta_{t}+\beta \cdot P O S T_{i} \times S O G_{c}+\gamma \cdot P O S T_{i}+$ controls $_{i c t}+\varepsilon_{i c t}$

where $\alpha_{c}$ is a country fixed effect, $\delta_{t}$ a temporal effect. $S O C$ is a dummy equal to 1 when country $c$ was a communist country. POST is equal to 1 when individual $i$ is born after 1970, and zero else. 
Table 3. The generational divide in post-communist countries

\begin{tabular}{lccc}
\hline \hline Dependent variable & $\begin{array}{c}\text { Opinion on 'private } \\
\text { ownership' }\end{array}$ & $\begin{array}{c}\text { Opinion on } \\
\text { 'owner control' }\end{array}$ & $\begin{array}{c}\text { Opinion on } \\
\text { 'competition is good' }\end{array}$ \\
\hline post-1990 & $-0.157^{* * *}$ & $-0.053^{* *}$ & $-0.092^{* * * *}$ \\
(Former Socialist country) & {$[0.020]$} & {$[0.022]$} & {$[0.021]$} \\
$\times$ (post-1990) & $0.435^{* * *}$ & $0.428^{* * *}$ & $0.236^{* * *}$ \\
Observations & {$[0.032]$} & {$[0.038]$} & {$[0.031]$} \\
\hline \hline
\end{tabular}

Notes: Logit estimates. All specifications include year fixed effects, country fixed effects and socio-demographic controls (age, income, education and gender - unreported coefficients). Column 1 uses 'private ownership' as the dependent variable; column 2 uses 'Owner control'; column 3 uses 'Competition is good'. 'Post-1990' is a dummy equal to 1 if the individual is 20 years old after 1990 (hence born after 1970). Standard errors are in parentheses. * Significant at $10 \%$; ** significant at $5 \%$; *** significant at $1 \%$.

Sources: WVS for attitudes and socio-demographics (see text).

The 'slow learning' theory predicts $\beta$ to be positive. This methodology generalizes a recent paper by Alesina and Fuchs (2007), whose focus, unlike ours, is on attitudes toward redistribution. They find that, in East Germany, older generations are much more likely to support income equality than newer ones, when compared to West Germany. They interpret this as evidence that people's preferences are shaped in their early adulthood by the economic system they live in. Like Alesina and Fuchs, our methodology is akin to a difference (across countries) in difference (across generations) approach. It has the advantage to control for possible differences in attitude across generations that would be the same across countries (the $\gamma$ coefficients), as well as country fixed effects.

Estimates of (2) are reported in Table 3, with different dependent variables. Column 1 uses attitudes toward 'private ownership' (as opposed to public ownership). Column 2 uses the 'owner control' variable (as opposed to firm control, by employees or the state). And column 3 uses attitudes toward 'competition'.

From Table 3 we get that the coefficient of POST is negative: younger generations are less pro-capitalism than older ones in countries that have not experienced a socialist regime. The difference is statistically significant at $1 \%$, but not large quantitatively. Using marginal estimates, we find that the probability that a young person supports private property over state ownership of firms is lower by 3 percentage points (compared to a sample mean of $63 \%$, and a mean of about $64 \%$ for non-former socialist economies). The probability of supporting control by owners only is lower by a tiny 1 percentage point (with a sample mean of $37 \%$ ). Opinions are less likely to be pro-competition by some 2 percentage points (sample mean: 75\%). Such differences between the young and the old are difficult to interpret economically. We paid attention to control for linear age effects in the regressions, but the POST dummy may still capture straight age effect, instead of a pure cohort effect. Thus, this difference in opinions may simply mean that younger people are inherently less confident in markets (out of, say, ideological reasons). Alternatively, it could be a generational effect. 
The more interesting fact from Table 3 is that the coefficient $\beta$ of the interaction term has the expected sign and is statistically significant in the three specifications: the generational divide is reversed in former socialist countries, where younger citizens are much more pro-capitalism than older ones. The difference is quantitatively sizeable. For a young person, the probability of supporting more private property is larger by 6 percentage points. For the second variable, the probability is larger by 8 percentage points. These two effects are much larger than what was found when we tested the 'self-interest hypothesis', which suggests that the 'slow learning hypotheses' can have, under such radical circumstances, a large explanatory power. Interestingly, we find that attitudes toward competition display the same type of feature, but that the difference across generations is smaller: some 3 percentage points. This gives us further confidence that individual beliefs in market forces are more coherent than what the 'pure self-interest hypothesis' would suggest.

The effects that we find are smaller than what Alesina and Fuchs (2007) have in their study of attitudes towards redistribution. In their paper, compared to people born after 1975, people from former East Germany born before 1960 are between 10 to 40 percentage points more likely to support a high level of redistribution (comparing to West Germans). This suggests that the forces that shape the preference for redistribution are not necessarily the same as those which shape attitudes toward market forces. Since the Berlin Wall fell, most former (i.e. old) residents of postcommunist countries may agree that private property and competition are better at getting things done than central planning but may still display strong preferences for redistribution (in particular since East Germany has received more than one trillion euros in transfers from West Germany since reunification).

\subsection{Domestic information bias}

We have shown the importance of path dependence in the formation of beliefs on economic systems. We now want to highlight a complementary mechanism of belief stickiness: when updating their beliefs about the efficiency of various economic systems, we ask if individuals overweight their own country's history, and underweight other countries' experiences. This, along with the persistence documented in Section 5.1 , would explain why cross-country differences in public opinion could persist.

For that purpose, we go back to our panel data and categorize countries as 'LDF' (less developed financially) if their level of financial development (the sum of stock market capitalization to GDP and private credit to GDP) is below median. This is the dimension of 'Economic systems' that we explore. We exploit our panel structure to look at whether good domestic economic performance leads to stronger beliefs about the local economic system. For individual $i$, in country $c$, in year $t$, our econometric specification is the following:

$$
\text { att }_{i c t}=\alpha_{c}+\delta_{t}+\gamma \cdot \text { Growth }_{c t}+\beta \cdot L D F_{c t} \times \text { Growth }_{c t}+\text { controls }_{i c t}+\varepsilon_{i c t}
$$


Table 4. When growth fails: attribution bias in pro-capitalism attitudes

\begin{tabular}{lcccccc}
\hline \hline & Firm private & \multicolumn{3}{c}{ Owner should control } & \multicolumn{2}{c}{ Competition is good } \\
\hline GDP Growth & $-0.039^{* * * *}$ & $-0.042^{* * *}$ & $0.052^{* * *}$ & $0.053^{* * * *}$ & $0.053^{* * * *}$ & $0.053^{* * *}$ \\
& $(0.009)$ & $(0.009)$ & $(0.011)$ & $(0.011)$ & $(0.008)$ & $(0.008)$ \\
GDP Growth*LDF & $0.028^{* * *}$ & $0.037^{* * * *}$ & $-0.062^{* * *}$ & $-0.064^{* * *}$ & $-0.046^{* * *}$ & $-0.032^{* * *}$ \\
& $(0.009)$ & $(0.010)$ & $(0.011)$ & $(0.012)$ & $(0.008)$ & $(0.009)$ \\
Other_System_Growth & & $0.056^{* * *}$ & & $0.038^{* *}$ & & $0.143^{* * *}$ \\
& & $(0.014)$ & & $(0.019)$ & & $(0.013)$ \\
Other_System_Growth*LDF & 0.030 & & $0.104^{* * *}$ & & $0.072^{* * *}$ \\
& & $(0.022)$ & & $(0.040)$ & & $(0.021)$ \\
Number of countries & 54 & 54 & 44 & 44 & 54 & 54 \\
Observations & 100600 & 99292 & 82946 & 80617 & 95765 & 95765 \\
Pseudo R ${ }^{2}$ & 0.07 & 0.07 & 0.05 & 0.05 & 0.04 & 0.04 \\
\hline \hline
\end{tabular}

Notes: Logit estimates. Attitude toward 'private firms' is the dependent variable in columns 1-2, 'owner control' in columns 3-4 and 'competition' in column 5-6. Socio-demographic controls include age, income, education and gender. LDF is a dummy equal to 1 if the country has above median financial development. GDP growth is current year own country GDP growth. 'Other system growth' is the average growth rate of countries that have $\mathrm{LDF}=1$ if the home country has $\mathrm{LDF}=0$, and conversely. All regressions include individual characteristics (gender, age, education), as well as country and year dummies. Error terms are clustered at the (country, year) level. Standard errors are in parentheses.

* Significant at $10 \%$; ** significant at $5 \%$; *** significant at $1 \%$.

Sources: WVS for attitudes and socio-demographics (see text), Penn World Tables for GDP growth, Beck and Levine (2004) for financial development (current year ratio of private credit and stock market capitalization to GDP).

which is estimated using a logistic regression. $\alpha_{c}$ is a country fixed effect, $\delta_{t}$ a temporal effect and Growth is the growth rate of GDP. To test how other countries' information enters the updating process, for each country-year $(c, t)$, we also construct 'Other_System_Growth', the mean growth in countries ruled by the other economic system than $c$ at year $t$ and perform the following regression:

$$
\begin{aligned}
\text { att }_{i c t}= & \alpha_{c}+\delta_{t}+\gamma \cdot \text { Growth }_{c t}+\beta \cdot L D F_{c t} \times \text { Growth }_{i c t}+\gamma^{\prime} \cdot \text { Other_System_Growth } \\
& \times \text { Other_System_Growth }+\beta \cdot L D F_{c t}+\text { controls }_{i c t}+\varepsilon_{i c t}
\end{aligned}
$$

We include country and time fixed effects and our individual controls are age, sex, education, income, and report the results in Table 4. In columns 1, 3 and 5, we report the estimates of Equation (3) for the two attitudes toward private profits, and for the belief in the virtue of competition. Columns 2, 4 and 6 contain the three estimates of Equation (4).

In four out of six specifications, the results are directionally coherent with Bayesian updating: in 'less financially developed' countries that perform well, individuals tend to become even more averse to surrendering the full control of firms to their owners, and doubt more often the virtues of competition. Yet, they seem, on average, to welcome more private ownership of firms. The effects are less large than in the section above. For instance, let us compare two countries whose growth rates are 2 percentage points apart (approximately one standard deviation). The differential support for owner control in market economies (compared to non-market economies) will be larger by some 2 percentage points. This is small compared to a sample mean of $37 \%$. 
Looking at columns 4 and 6, we see that while not totally neglecting information from other countries, individuals seem to rely more heavily on their own country's history to update their beliefs about the virtues of markets, even though, from the perspective of an econometrician, a single (growth, country, year) observation is unlikely to have a significant impact on the beliefs one should hold about the efficiency of markets.

Thus, the evidence of Table 4 is consistent with the fact that growth is attributed to the merits of the system in place, so that the beliefs in the current system become stronger in high growth times. We do not find direct evidence for confirmatory bias as negative information coming from the good performance of opposite economic systems seems to be taken into account by individuals in their revisions. All in all, these results are consistent with Piketty (1995)'s intuition: the beliefs of a country's population might not converge due to the over-sampling of information coming from one's own country.

\section{CROSS-COUNTRY EVIDENCE: CULTURE AND ECONOMIC ATTITUDES}

Using individual data, our study of the determinants of economic attitudes concludes to the importance of sticky beliefs. In this context, the country fixed effects in our individual regressions can tentatively be interpreted as capturing country-specific cultural traits. A theory of the origin of culture is of course largely beyond the scope of this paper, but, while remaining cautious on the interpretation, we ask here how economic attitudes across countries relate to other cultural variables. The variables we look at are the following:

- Religion: In his famous essay, 'The Protestant Ethic and the Spirit of Capitalism', Max Weber developed the thesis that Calvinism had a major facilitation role on the development of capitalism in Europe and the United States. Guiso et al. (2003b) have shown that religion is correlated with a wide range of economic attitudes. They find the Jewish and Protestant religions to be more correlated with the presence of pro-capitalism preferences, and that in general being religious is positively correlated with a positive perception of work and thrift. To explore the impact of religion on cross-country economic attitudes, we use the data from Botero et al. (2004) which give the percentage of different religions (Protestant, Muslim and Catholic) in the population of countries in 1980.

- Trust: Many existing studies have shown that trust explains well the cross section of various economic outcomes, such as GDP growth (Knack and Keefer, 1997), the existence of large firms (La Porta et al., 1999), or the quality of labour relations (Algan and Cahuc, 2007). More related to our work, Guiso et al. (2005) have shown that trust is positively correlated with stock-market participation, both at the country and at the individual level. The level of trust is therefore a natural candidate when it comes to explain differences in attitudes toward markets. The 
related question in the WVS is 'Generally speaking, would you say that most people can be trusted or that you need to be very careful in dealing with people?' We construct a variable equal to 1 when the respondent answers that 'most people can be trusted', and take the mean of this variable at the country level.

- Legal Origin: In a series of influential papers, Laporta, Lopez-de-Silanes, Shleifer and Vishny find that, in the cross-section of countries, legal origins (UK common law versus French civil law) are strong predictors of economic institutions. The interpretation of this correlation remains open to debate, some authors arguing that it may be driven by the political equilibrium, much more than legal institutions themselves (see Rajan and Zingales, 2003a; Perrotti and Von Thadden, 2006, among others). For our purpose, including legal origin is a natural way to get a first shot at isolating the long-run historical and institutional determinants of economic sentiment.

We collapse our individual data at the country level variable by taking the mean of each variable and then we regress our measures of economic attitudes on the above country-level cultural variables:

att $_{c}=\alpha+\beta \cdot{ }^{\text {'cultural variable }}{ }_{\mathrm{c}}+$ controls $_{c}+\varepsilon_{c}$

Table 5 reports the OLS regression results. For each attitude, in one out of four specifications, we include population size (resp. GDP per capita) as controls to make sure that our cultural variables are not simply capturing the opposition of large versus small (resp. rich versus poor) countries.

A bit less than half of the cross-country variation in economic attitudes is explained by the variables we have chosen. Trust appears positively related to attitudes toward 'private firm' but not toward the other two pro-capitalism attitudes. Confirming Max Weber's theory, the fraction of Protestants is positively related to the pro-capitalism attitudes in a country, significantly so for 'Firm Private' and 'Owner Control'. The most surprising result is perhaps the strong explanatory power of Legal Origin. Note that in these regressions British legal origin is the default. Legal origin has a significant impact and substantially increases all the regressions R-squared. Notably, French legal origin is strongly related to competition aversion and British common law to a strong preference for owner control. Interestingly, in non-reported regressions, we found that countries with Scandinavian and German legal origins tend to be the ones that support 'joint management by owners and workers' the most. These countries actually tend to be ones where this joint management is actually favoured by law and the structure of collective bargaining (Algan and Cahuc, 2007). While it convincingly shows the link between long-run history and current beliefs, the interpretation of the role of legal origin is somewhat ambiguous. In the context of the 'slow learning hypothesis', one can interpret legal origin as a proxy for some cultural traits that have subsisted and still determine pro-market attitudes. But one could also favour an interpretation more aligned with the 'self-interest' view: Legal origin might determine 
Table 5. Gultural variables and cultural attitudes across countries

\begin{tabular}{|c|c|c|c|c|c|c|c|c|c|c|c|c|}
\hline \multirow[t]{2}{*}{ Dependent variable } & \multicolumn{4}{|c|}{ Firm private } & \multicolumn{4}{|c|}{ Owner should control } & \multicolumn{4}{|c|}{ Competition is good } \\
\hline & 1 & 2 & 3 & 4 & 5 & 6 & 7 & 8 & 9 & 10 & 11 & 12 \\
\hline Trust & $\begin{array}{r}0.234^{*} \\
(-0.119)\end{array}$ & & & $\begin{array}{l}-0.086 \\
(-0.125)\end{array}$ & $\begin{array}{l}-0.035 \\
(-0.106)\end{array}$ & & & $\begin{array}{l}-0.045 \\
(-0.104)\end{array}$ & $\begin{array}{l}-0.038 \\
(-0.061)\end{array}$ & & & $\begin{array}{l}-0.120^{*} \\
(-0.064)\end{array}$ \\
\hline Catholic & & $\begin{array}{c}0.000 \\
(0.000)\end{array}$ & & $\begin{array}{c}0.001 \\
(-0.001)\end{array}$ & & $\begin{array}{l}0.001 * * \\
(0.000)\end{array}$ & & $\begin{array}{l}0 \\
(0.000)\end{array}$ & & $\begin{array}{c}-0.000^{*} \\
(0.000)\end{array}$ & & $\begin{array}{c}0.000 \\
(0.000)\end{array}$ \\
\hline Muslim & & $\begin{array}{l}-0.001 \\
(-0.001)\end{array}$ & & $\begin{array}{c}0.001 \\
(-0.001)\end{array}$ & & $\begin{array}{c}0.001 \\
(-0.001)\end{array}$ & & $\begin{array}{c}0 \\
(-0.001)\end{array}$ & & $\begin{array}{c}0.000 \\
(0.000)\end{array}$ & & $\begin{array}{c}0.000 \\
(0.000)\end{array}$ \\
\hline Protestant & & $\begin{array}{l}0.003^{* * * *} \\
(-0.001)\end{array}$ & & $\begin{array}{c}0.002 \\
(-0.001)\end{array}$ & & $\begin{array}{l}0.002 * * * * \\
(-0.001)\end{array}$ & & $\begin{array}{c}0.002^{*} \\
(-0.001)\end{array}$ & & $\begin{array}{c}0.000 \\
(0.000)\end{array}$ & & $\begin{array}{c}0.001 \\
(0.000)\end{array}$ \\
\hline Leg. Orig. French & & & $\begin{array}{l}-0.089 * \\
(-0.045)\end{array}$ & $\begin{array}{l}-0.135^{* * * *} \\
(-0.041)\end{array}$ & & & $\begin{array}{l}-0.077 * * \\
(-0.035)\end{array}$ & $\begin{array}{l}-0.089 * * \\
(-0.035)\end{array}$ & & & $\begin{array}{l}-0.052^{* *} \\
(-0.021)\end{array}$ & $\begin{array}{l}-0.066^{* * * *} \\
(-0.019)\end{array}$ \\
\hline Leg. Orig. German & & & $\begin{array}{c}0.094 \\
(-0.069)\end{array}$ & $\begin{array}{c}0.011 \\
-0.056)\end{array}$ & & & $\begin{array}{l}-0.074 \\
(-0.05)\end{array}$ & $\begin{array}{l}-0.100 * * \\
(-0.044)\end{array}$ & & & $\begin{array}{l}-0.026 \\
(-0.031)\end{array}$ & $\begin{array}{l}-0.012 \\
(-0.023)\end{array}$ \\
\hline Leg. Orig. Scandinav. & & & $\begin{array}{l}0.157^{* *} \\
(-0.074)\end{array}$ & $\begin{array}{l}-0.034 \\
(-0.098)\end{array}$ & & & $\begin{array}{l}-0.067 \\
(-0.056)\end{array}$ & $\begin{array}{l}-0.240^{* * * *} \\
-0.08\end{array}$ & & & $\begin{array}{l}-0.005 \\
(-0.033)\end{array}$ & $\begin{array}{l}-0.011 \\
(-0.041)\end{array}$ \\
\hline Leg. Orig. Socialist & & & $\begin{array}{l}-0.046 \\
(-0.046)\end{array}$ & $\begin{array}{l}-0.048 \\
(-0.041)\end{array}$ & & & $\begin{array}{l}-0.167 \text { **** } \\
(-0.035)\end{array}$ & $\begin{array}{l}-0.201 * * * \\
(-0.034)\end{array}$ & & & $\begin{array}{c}0.006 \\
(-0.021)\end{array}$ & $\begin{array}{l}-0.008 \\
(-0.017)\end{array}$ \\
\hline GDP per capita (log) & & & & $\begin{array}{c}0.061^{* * *} \\
(-0.024)\end{array}$ & & & & $\begin{array}{l}-0.008 \\
(-0.02)\end{array}$ & & & & $\begin{array}{l}-0.019^{*} \\
(-0.01)\end{array}$ \\
\hline Population (log) & & & & $\begin{array}{l}-0.008 \\
(-0.01)\end{array}$ & & & & $\begin{array}{l}-0.020 \text { ** } \\
(-0.009)\end{array}$ & & & & $\begin{array}{l}-0.001 \\
(-0.004)\end{array}$ \\
\hline Observations & 82 & 77 & 79 & 75 & 80 & 75 & 77 & 74 & 76 & 71 & 73 & 70 \\
\hline $\mathrm{R}^{2}$ & 0.05 & 0.26 & 0.19 & 0.46 & 0.00 & 0.12 & 0.24 & 0.47 & 0.01 & 0.12 & 0.14 & 0.44 \\
\hline
\end{tabular}

Notes: Attitudes are computed as averages over individuals and survey waves, such that there is only one observation per country. This table presents plain OLS estimates. The fraction of individuals in different religions comes from Botero et al. (2004) and is measured in 1980. Attitude toward 'Private Firm' is the dependent variable in columns 1-4, 'Owner control' is the dependent variable in columns 5-8 and 'Competition is good' in columns 9-12.

***, **, * stand for significant at the 1,5 and 10\% levels.

Sources: WVS for attitude variables (see text), Penn World Tables for Population and GDP. 
persistent differences in the distribution of rents which explain its explanatory power on today's attitudes. We remain agnostic between these two interpretations.

Legal origin and, to a large extent, religion are variables determined by a country's pre-20th century history. These last results suggest that country level attitudes are basically shaped by long-run institutional forces rooted in the history and culture of a country rather than by recent trends and transformations.

\section{DO BELIEFS AFFECT THE ADOPTION OF ECONOMIC REFORMS?}

From a policy point of view, understanding the determinants of pro capitalism attitudes is important because attitudes are likely to affect the feasibility of economic reforms. Is there evidence of such causality from aggregate beliefs to country's institutions?

A recent economic literature attempts to show that national opinions do shape economic institutions and performance. For example, Algan and Cahuc (2005) argue that civic attitudes affect the performance of labour market institutions. They use as instrumental variables for today's opinion the civic attitudes of descendants of emigrants to the US. Tabellini (2007) complements Knack and Keefer's (1997) findings by showing that social capital, measured as trusting attitudes, predicts economic development in regions of Europe.

Before investigating causality, we can see from Figure 1 that attitudes toward private ownership are strongly correlated with the market friendliness of economic institutions. Each panel explores the cross-country correlation between the average support for private business (defined as the share of citizens who think that private ownership of firms is more desirable than government ownership) and the extent of various pro-market institutions: a de jure index of product market deregulation (defined as the opposite of the index of regulatory barriers to entry taken from Djankov et al., 2002); a de facto measure of financial development (see Section 3); a de jure measure of financial development (from Kaminsky and Schmukler, 2008); and a de facto measure of pension funding (see Section 3). It clearly appears that in countries where private ownership receives strong support in public opinion, product market entry is less difficult, financial development is high and pensions tend to be more funded.

In Table 6 we provide some suggestive evidence that these correlations may be interpreted causally. ${ }^{4}$ Columns 1, 3, 5 and 7 report the results of OLS estimates corresponding to the scatter plots in Figure 1. Obviously, those correlations between attitudes and institutions could reflect a two-way causation or could be driven by

\footnotetext{
4 Table 6 reports only the specifications where our variable of interest is attitude toward 'private ownership'. Results for attitudes toward 'owner control' and 'competition is good' are not reported and are available upon request from the authors. For 'owner control' the estimates on the coefficient of interests are similar for the signs and the statistical significance in simple regressions (i.e. columns 1, 3, 5, 7) and similar for the signs only, in the interacted regressions (columns 2, 4, 6, 8). For 'Competition is good' the coefficients are never significant.
} 

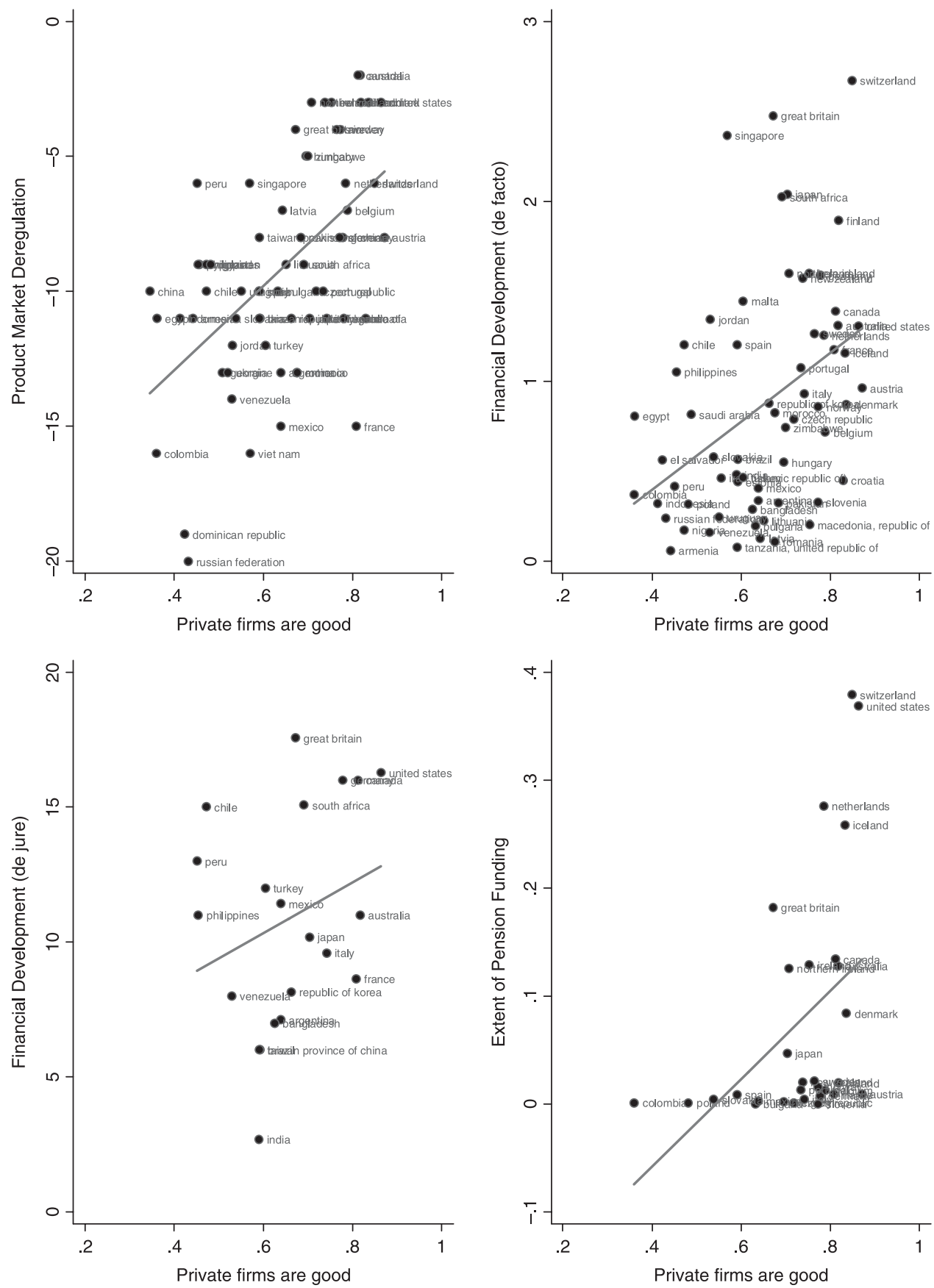

Figure 1. Pro-capitalism and market friendly institutions 


\section{Table 6. Institutions and pro-capitalism}

\begin{tabular}{|c|c|c|c|c|c|c|c|c|}
\hline \multirow[t]{2}{*}{ Dependent variable } & \multicolumn{2}{|c|}{$\begin{array}{c}\text { Product market } \\
\text { deregulation (de jure) }\end{array}$} & \multicolumn{2}{|c|}{$\begin{array}{l}\text { Financial development } \\
\text { (de facto })\end{array}$} & \multicolumn{2}{|c|}{$\begin{array}{l}\text { Financial development } \\
\text { (de jure })\end{array}$} & \multicolumn{2}{|c|}{$\begin{array}{l}\text { Extent of pension } \\
\text { funds (de facto) }\end{array}$} \\
\hline & 1 & 2 & 3 & 4 & 5 & 6 & 7 & 8 \\
\hline \multirow[t]{2}{*}{ 'Private Ownership' } & $15.6^{* * * *}$ & -1.5 & $1.9 * * *$ & -0.8 & 9.4 & $-47.9 *$ & $0.4^{* *}$ & $-0.9 *$ \\
\hline & {$[3.3]$} & {$[6.6]$} & {$[0.5]$} & {$[1.0]$} & {$[7.2]$} & {$[24.2]$} & {$[0.2]$} & {$[0.5]$} \\
\hline \multirow[t]{2}{*}{ 'Priv.Owner.' $\times$ democracy } & & $2.4^{* * *}$ & & 0.2 & & $5.7 *$ & & $0.1 *$ \\
\hline & & {$[0.8]$} & & {$[0.1]$} & & {$[2.9]$} & & {$[0.1]$} \\
\hline \multirow[t]{2}{*}{$\log ($ GDP per cap) } & & 0.1 & & $0.4^{* * * *}$ & & 2.3 & & -0.0 \\
\hline & & {$[0.7]$} & & {$[0.1]$} & & {$[1.8]$} & & {$[0.1]$} \\
\hline \multirow[t]{2}{*}{ Democracy } & & $-1.4^{* * *}$ & & -0.1 & & $-3.5 * *$ & & -0.1 \\
\hline & & {$[0.4]$} & & {$[0.1]$} & & {$[1.6]$} & & {$[0.0]$} \\
\hline Observations & 63 & 59 & 63 & 58 & 21 & 21 & 30 & 28 \\
\hline \multicolumn{9}{|l|}{ (No of countries) } \\
\hline $\mathrm{R}^{2}$ & 0.30 & 0.40 & 0.17 & 0.41 & 0.08 & 0.36 & 0.18 & 0.26 \\
\hline
\end{tabular}

Note: The measure of Product Market Deregulation is minus the number of steps needed to start a business (Djankov et al., 2002). It is larger (closer to zero) when entry is less regulated. The de facto measure of financial development is taken from Beck and Levine's (2004) most recent database, and is computed as the ratio of private credit and stock market capitalization to GDP. The measure of De Jure Financial Development is taken from Kaminsky and Schmukler (2008) composite index ranking between 0 and 3. Both measures are larger when the financial industry is more developed. Extent of Pension Funds is measured as the 2003 ratio of life insurance and pension funds liabilities to GDP 'Private ownership' is a country level average measures of attitudes toward private firms (as opposed to state ownership). It is larger when the country is more 'pro market'. Democracy is an index from Polity IV dataset: it is higher, the more democratic the institutions. Standard errors are in brackets.

* Significant at $10 \%$;* significant at $5 \%$; *** significant at $1 \%$. 
omitted variables. We have no instrumental variable, but we take a first step in this direction by asking whether these correlations are higher in countries where the median voter is more influential, i.e. democracies. Thus, we regress our various institution variables on attitudes toward private ownership interacted with the extent of democracy (from the Polity IV Dataset). This interaction term is intended to capture the causal effect of attitudes toward institutions. We also control for obvious correlates of institutions and attitudes such as GDP per capita and democracy. As it appears from column 2, 4, 6 and 8, in three out of four specifications, the market friendliness of institutions is significantly more impacted by average opinion in democracies than in more autocratic regimes. This is consistent with public opinions having an impact on economic institutions.

\section{CONCLUSION}

According to neo-classical economists, Pareto-improvements can be reached if market-friendly reforms are taking place simultaneously with the compensation of individuals losing rents in those reforms. However, pro-market politicians often fail to convince a majority of individuals that such economic reforms can ultimately benefit them. The goal of this paper was to investigate the origins of anti-market sentiment and to understand better its variations across populations, countries and time.

Our results are twofold: First, we find that the traditional 'self-interest hypothesis' according to which individuals hold political opinions that are self-serving indeed receives some support from the data. Yet, their explanatory power is small. Second, we find that learning about the merits of economic systems has some degree of sub-optimality. Economic experiences in early adulthood, idiosyncratic performances of the domestic economy, rather than foreign countries' experiences, matter a lot in shaping beliefs about economic systems. We show that the explanatory power of the 'slow learning' hypothesis is larger than the effects generated by the 'self-interest hypothesis'.

Our results suggest that economic reform's feasibility does not depend solely on its impact on the distribution of rents; ideological a-priori beliefs are likely to be important determinants as well. Politicians are more likely to successfully pass pro-market reforms in times where the economic performance of the country is lower because these are times where the aggregate efficiency of the current system is put into doubt.

\section{Discussion}

\section{Maristella Botticini}

Università di Torino

This paper adds a novel contribution to the empirical literature that investigates the interactions between cultural values and economic variables. The empirical analysis 
relies on the World Value Survey (supplemented with other datasets). The main findings are threefold. First, at the individual level, there seems to be support for the theory that individuals who have less to gain from pro-markets institutions, tend to disfavour them. Second, at the country level, rent-seeking explanations of economic beliefs explain little of the cross-country differences in anti-market sentiment. Third, cross-country differences in anti-market sentiment seem to depend on past cultural and historical factors.

I think this work asks a policy relevant question for policy makers who intend to implement a policy change. However, I have to be critical for a variety of reasons. The paper refers to some papers and theories but it does not spell out clearly which specific model is going to be estimated or tested. This is not the main goal of this work but the paper would gain in clarity if a model is presented, spelled out clearly, and then estimated or tested. The section on the two theories is important because it should provide the theoretical background to the empirical exercise in the subsequent sections. This section can be improved by clarifying what exactly is the theory or theories that are going to be tested or the model that is going to be estimated.

With the caveat regarding the 'theory' mentioned above, the empirical exercise is executed in a competent way. Most findings are convincing and seem reasonable. Nevertheless, the criticisms and scepticism about using the World Value Survey (and similar surveys) - e.g. what is the incentive for people to provide truthful information, whether people understand correctly the questions, etc. - apply to this paper, as well as to other works based on similar datasets.

The discussion of the finding that people with higher incomes show strong support for market forces and competition is not very clear. The same applies to the discussion about why skilled workers may favour competition. This comment goes back to the general point raised above: what model or what theory is going to be tested in this paper? Finally, it would have been interesting to get an intuition about the interesting (actually puzzling) finding that richer countries show less support for competition.

\section{Kevin O'Rourke \\ Trinity College Dublin}

Let me say at the outset that I found this paper to be clearly structured and interesting, and that its consistent methodology made for a coherent and convincing piece of work. As to the main purpose of the article, understanding what the authors call 'capitalism aversion' is to my mind, given my background and training, an essentially historical task. At least, it would be historical, unless you accept that the pure rational choice model focused on individual self-interest was the only force shaping individual political preferences, a claim which presumably no-one takes particularly seriously, and which in any event the authors of this paper do a good job of debunking.

The alternative to rational self-interest that the authors consider is labelled by them 'slow learning', which as they note is consistent with rationality if there are costs 
of acquiring information. If the costs of acquiring information about other countries were higher than the costs of acquiring information about one's own country, and I suppose that they are, then it would also be rational to 'overweight' information about one's own country when updating one's beliefs, which is something that the authors say happens in practice, based on their results. Actually, I was not convinced by this conclusion of the paper, since Table 4 seemed to me to show that respondents did take into account information from other countries when forming their beliefs, and I had no way of figuring out if the sizes of the coefficients involved implied 'oversampling' or 'under-sampling' of particular types of information.

A broader question that I have, however, and to my mind a more important one, is the extent to which we should lock ourselves into the sort of rational interpretation of beliefs and values that the 'slow learning' label implies. I thus found myself wondering whether 'interests versus slow learning' is really the key distinction that the authors should be focusing on, or at least whether these are the right labels. What about the far more widespread distinction which political scientists make between 'interests and ideology', or, more neutrally, between 'interests and ideas'? Anyone who has read through British Parliamentary debates regarding trade policy during the late 19th century will have been struck by the hold which free trade ideology had on the participants in those debates. Presumably if former occupants of the Communist bloc are more anti-capitalist than others, this is at least in part because ideas - in this case Marxist ones - have an independent life of their own (and not just because these people went through a different economic history, and learned accordingly). Schools, families, religions and political parties all matter for beliefs. Geoff Harcourt once told me that if you knew someone's position on the Vietnam War, you could accurately predict their position on the Cambridge Capital Controversy. That may be too glib (and indeed the statement was made in a pub), but still, values and ideology do help shape peoples' attitudes, or at least there are an awful lot of academics out there who think they do.

In my own work with Richard Sinnott on attitudes towards trade and immigration (O'Rourke and Sinnott, 2001b, 2006) we found that the most important variables explaining these attitudes were not economic, but rather non-economic factors such as nationalism and chauvinism. Of course, this is not what we emphasized when writing up the paper, since otherwise we would never have been published by an economics journal. Happily for us, interests also mattered, as indicated by the differential impact of skills on attitudes across countries, but in fact these Heckscher-Ohlin variables which we used to sell the papers to economists were a lot less important quantitatively than either nationalism or chauvinism. Thus, being high-skilled reduced the probability of the most protectionist response by between 2.29 and 8.44 percentage points, depending on the income (and skill-endowment) of the economy, but moving chauvinism from the 20th to the 80th percentile increased the probability of the most protectionist response by nearly 20 percentage points (as compared with a benchmark probability for that response of some $31 \%$ ). 
Now, some might respond that nationalism and chauvinism could be endogenous, but gender surely is not, and our results found that the next most important influence on attitudes towards trade is in fact gender. For example, being a woman increased the probability of the most protectionist response by 7.39 percentage points, a big number. Why are women more anti-trade than men? Why are Latin American women more anti-market in general than Latin American men (Graham and Pettinato, 2001, Table IV, p. 258)? Why, on the other hand, are women not systematically more anti-immigrant than men, despite the fact that immigration and trade have similar effects on income distribution in many trade models? And why are women significantly less anti-refugee than men? I challenge anyone to find a rational choice explanation for such findings, and I am pretty sure that 'slow learning' would not be my preferred alternative. Apparently there exists a psychology literature on differences in moral reasoning between men and women that might be relevant, but as an economist I am permitted to remain unaware of such things, even though they appear to be potentially hugely important.

Back to slow learning. Even if, as indeed seems likely, preferences only evolve slowly, then one still has to ask: 'What do they evolve slowly from?' And why should the starting point have been different in France or in the United States? Here, if the promise of this paper is to be fully fulfilled - and of course I recognize that this is the subject matter not for a journal article, but for a book - the authors will have to engage deeply with the historical literature, for example with Eric Rauchway's recent argument that the peculiarities of American political development can be traced back to the particular way in which the US interacted with the 19th-century world economy: Rauchway, 2006). It is a striking feature of this paper that its bibliography is uniquely composed of references to other economists, when one might have thought that the work of historians, political scientists, psychologists, and sundry others might have been relevant as well. This is in no way a criticism of the authors and the paper, but it is a criticism of modern economics: if it wants to imperialistically invade other people's intellectual turf, it might occasionally take the time to listen to the natives, who may have some helpful lessons to pass on about their local environment.

Furthermore, I am pretty sure that most historians would look askance on the current fad in economics of claiming that we can understand the role of history in explaining current beliefs, institutional structures or performance by running regressions incorporating such crude variables as religious affiliation or 'legal origin', as is done in Section 6. Never mind the fact that when you look in detail at the evolution of particular laws thought to matter for economic performance, such as bankruptcy law, what you find is that such laws evolved very similarly throughout Europe during the 19th century, no matter whether the country in question was Germanic, Latin or Anglo-Saxon (Sgard, 2006); or that Weber's thesis has at this stage been comprehensively debunked by historians and social scientists. More fundamentally, I think most historians would probably take the view that events are important in the long as well as the short run. We are all familiar with the argument that German hostility to 
inflation arises from the experience of hyperinflation after World War I, or that the British obsession with exchange-rate policy can be traced back to the supposedly damaging consequences of sterling's return to gold in the 1920s. Might not attitudes towards capitalism also depend, not on the supposedly immutable cultural characteristics of populations, but on countries' histories? This would of course be more consistent with the 'slow learning' hypothesis which is the main focus of this paper.

I'd like to end with a suggestion. In favour of the authors' conclusions concerning slow learning is the fact that, probably (because I don't have the empirical evidence), big policy shocks have indeed had large and long-lasting effects on attitudes. When Ryanair was allowed to compete on the British-Irish air routes in the 1980s, this had an immediate effect on airfares and passenger traffic, on what had previously been the most expensive route per mile in the world. Anecdotal evidence suggests that this revolutionized Irish attitudes towards competition. Another such example that might be relevant for this paper is Mrs Thatcher's selling off council homes to tenants: did this (or the floating of national utilities) influence British people's attitudes towards private property and the profit motive? Could one look at such privatizations in countries where the market subsequently rose, and see if the impact on attitudes was different from countries in which the market subsequently fell? Did the relative speed of reform programmes in different former Communist economies, in combination with those countries' relative successes, have durable effects on attitudes? I'll bet there are substantial literatures on at least some of these questions, which might bolster the authors' case. If not, there is a nice research agenda there for someone - possibly these authors? - to pursue.

\section{Panel discussion}

Luigi Guiso pointed out that the main question relates to the correlation between the spread out of capitalism and what people think about capitalism, and concerns the direction of causality. The debate dates back to Marx, who argued that it is the structure of the economy that leads to a cultural superstructure, and Max Weber, who thought the opposite in his essays on the spirit of capitalism. Overall, beliefs are important and there are several reasons why we should be worried about them. As a criticism of the paper, he stressed that the debate is not really between rationality and irrationality. Indeed, it is perfectly rational that people act according to their belief, and if they are taking into account well-being at the society level as well as at the individual level, it simply means that they derive utility from several factors. Alan Drazen pointed out that even if attitudes drive actions, the real problem is that reported feelings can very likely not be what determine the actual behaviour. He was also critical about the authors' claim that the result (in Table 2) that richer people support competition more was surprising. Perhaps this simply reflects a view of 'competition' as something related to lower taxes. Christian Schultz wondered if more 
competition can make countries wealthier, thus raising a concern about whether there could be a reverse causality. Pierre-Yves Geoffard added that the rich may well be in favour of competition, depending however on age, that is, on the time horizon over which competition can shape their life. Hans-Werner Sinn remarked that people who have financial wealth can be in favour of competition when the economy is open. In rich countries workers suffer from competition from low-wage countries and thus call for protectionism, while rich people get more returns on their wealth and should benefit from competition. Finally, Georges de Ménil commented on what can be learnt from the socialist transition. The way and speed people changed their attitudes is not an example of slow learning at all: despite the common prior that it would have required decades for ex-communists to think in terms of another system, attitudes changed very quickly.

\section{APPENDIX}

Table A1. Sample statistics of attitudes and socio-demographics

\begin{tabular}{|c|c|c|c|}
\hline Variable & Observations & Mean & St. Deviation \\
\hline \multicolumn{4}{|l|}{ Pro market attitudes } \\
\hline Owners should run the firm & 190405 & 0.37 & 0.48 \\
\hline Private ownership should be increased & 204478 & 0.63 & 0.48 \\
\hline Pro competition & 201592 & 0.75 & 0.25 \\
\hline \multicolumn{4}{|l|}{ Socio demographics } \\
\hline Age (years) & 264893 & 41.23 & 16.33 \\
\hline Female & 267714 & 0.52 & 0.50 \\
\hline Income medium & 227589 & 0.37 & 0.48 \\
\hline Income high & 227589 & 0.29 & 0.45 \\
\hline Education medium & 187722 & 0.43 & 0.49 \\
\hline Education high & 187722 & 0.21 & 0.41 \\
\hline
\end{tabular}

Notes: Variable construction for pro market attitudes are described in the main text. 'Age' is in years. 'Female' is a dummy equal to 1 if the respondent is a woman. The last four variables are dummy variables directly obtained from the WVS. Hence, $52 \%$ of the respondents in the sample are women.

Source: World Value Survey (1980-2004).

\section{REFERENCES}

Acemoglu, D. (2003). 'Why not a political Coase theorem? Social conflict, commitment and politics', Fournal of Comparative Economics, 31(4), 620-52.

Alesina, A., E. Glaeser and B. Sacerdote (2001). 'Why doesn't the United States have a European-style welfare state', Brookings Papers on Economic Activity, 2, 187-254.

Alesina, A. and N. Fuchs (2007). 'Goodbye Lenin (or not)? The effect of communism on people's preferences', American Economic Review, 97, 1507-28.

Alesina, A. and E. Laferrara (2000). 'Participation in heterogeneous communities', Quarterly Fournal of Economics, 115, 847-904.

Alesina, A. and D. Rodrik (1994). 'Distributive politics and economic growth', Quarterly fournal of Economics, 109, 465-90.

Algan, Y. and P. Cahuc (2005). 'Civic culture and the design of labor market institutions', IZA Working Paper 2005-19. 
- (2007). La société de défance: comment le modèle social français s'autodétruit, Editions de la Rue d'Ulm.

Azmat, G., A. Manning and J. Van Reenen (2007). 'Privatization, entry regulation and the decline of labors share of GDP: A cross-country analysis of the network industries', CEP Discussion Papers No. 0806, Centre for Economic Performance, LSE.

Basu, K. (1992). 'Comment on the paper by Paul Romer', in L. Summers (ed.), World Bank Annual Conference in Development Economics, Washington DC.

Beck, T. and R. Levine (2004). 'Stock markets, banks, and growth: Panel evidence', fournal of Banking \& Finance, 28, 423-42.

Bertrand, M. and S. Mullainathan (2003). 'Enjoying the quiet life? Corporate governance and managerial performances', Fournal of Political Economy, 111, 1043-75.

Botero, J., S. Djankov, R. La Porta, F. Lopez-De-Silanes and A. Schleifer (2004). 'The regulation of labor', Quarterly Journal of Economics, 119, 1339-82.

Delpla, J. and C. Wyplosz (2007). La fin des privilèges: Payer pour réformer, Hachette Littérature, Paris.

Di Tella, R., S. Galiani and E. Schargrodsky (2007). 'The formation of beliefs: Evidence from the allocation of land titles to squatters', Quarterly Fournal of Economics, 122, 209-41.

Di Tella, R. and R. McCulloch (2004). 'Why doesn't capitalism flow to poor countries', mimeo, Harvard Business School.

Djankov, S., R. La Porta, F. Lopez-De-Silanes and A. Shleifer (2002). 'The regulation of entry', Quarterly Fournal of Economics, 117, 1-37.

Glaeser, E. (2006). 'Paternalism and psychology', The University of Chicago Law Review, 73, 13356.

Graham, C. and S. Pettinato (2001). 'Happiness, markets, and democracy: Latin America in comparative perspective', Journal of Happiness Studies, 2, 237-68.

Guiso, L., M. Haliassos and T. Jappelli (2003a). 'Household stockholding in Europe: where do we stand and where do we go?', Economic Policy, 18, 123-70.

Guiso, L., P. Sapienza and L. Zingales (2003b). 'People's opium? Religion and economic attitudes', Fournal of Monetary Economics, 50, 225-82.

- (2005). 'Trusting the stockmarket', NBER Working Paper, No. 11648.

Kaminsky, G. and S. Schmukler (2008). 'Short-run pain, long-run gain: The effects of financial liberalization', forthcoming, Review of Finance.

Kaplan, S. (1989). 'The effects of management buyouts on operating performance and value', Fournal of Financial Economics, 24, 217-54.

Kennickel, A. (2006). 'Currents and undercurrents: Changes in the distribution of wealth, 1989-2004', FEDS Working Papers No. 2006-13.

Knack, S. and P. Keefer (1997). 'Does social capital have an economic payoff? A cross-country investigation', Quarterly Journal of Economics, 112, 1251-88.

La Porta, R., F. Lopez-De-Silanes, A. Shleifer and R. Vishny (1999). 'Corporate ownership around the world', Fournal of Finance, 54, 471-517.

Luttmer, E. (2001). 'Group loyalty and the taste for redistribution', Fournal of Political Economy, 109, 500-28.

Mayda, A.M. (2006). 'Who is against immigration? A cross country investigation of individual attitudes towards immigration', Review of Economics and Statistics, 88, 510-30.

Mayda, A.M. and D. Rodrik (2005). 'Why are some people (and countries) more protectionist than others?', European Economic Review, 49, 1393-491.

Metzler, A. and S. Richard (1981). 'A rational theory of the size of government', fournal of Political Economy, 89, 914-27.

O'Rourke, K. and R. Sinnott (2001a). 'The determinants of individual trade policy preferences: International survey evidence', CEG Working Paper No. 2001-6.

- (2001b). 'What determines attitudes towards protection? Some cross-country evidence'. In S.M. Collins and D. Rodrik (eds.), Brookings Trade Forum (pp. 157-206). Washington DC: Brookings Institution Press.

- (2006). 'The determinants of individual attitudes towards immigration', European fournal of Political Economy, 22, 838-61.

O'Rourke, K. and J. Williamson (1999). Globalization and History: The Evolution of a 19th Century Atlantic Economy, Cambridge, MA: MIT Press.

Pagano, M. and P. Volpin (2005). 'The political economy of corporate governance', American Economic Review, 95, 1005-30. 
Penn World Tables, available at http://pwt.econ.upenn.edu/.

Perrotti, E. and E.L. Von Thadden (2006). 'The political economy of corporate control and labor rents', Fournal of Political Economy, 114, 145-74.

Piketty, T. (1995). 'Social mobility and redistributive politics', Quarterly Fournal of Economics, 110 , 551-84.

Rabin, M. and J. Schrag (1999). 'First impressions matter: A model of confirmatory bias', Quarterly Fournal of Economics, 114, 37-82.

Rajan, R. and L. Zingales (2003a). 'The great reversals: The politics of financial development in the 20th century', Fournal of Financial Economics, 69, 5-50.

- (2003b). Saving Capitalism from the Capitalists. New York: Crown Business.

Rauchway, E. (2006). Blessed Among Nations: How the World Made America. New York: Hill and Wang.

Robinson, J. (1998). 'Theories of "bad" policy', Fournal of Policy Reform, 2, 1-46.

Sgard, J. (2006). 'Do legal origins matter? The case of bankruptcy laws in Europe 1808-1914', European Review of Economic History, 10, 389-419.

Tabellini, G. (2007). 'Culture and institutions: Economic development in the regions of Europe', IGIER Working Paper No. 292.

Thesmar, D. and M. Thoenig (2006). 'Financial development and the rise of firm level uncertainty', mimeo, University of Geneva and HEG.

Weber, M. (2002). The Protestant Ethic and the Spirit of Capitalism, 3rd edn, edited by S. Kalberg. Los Angeles, CA: Roxbury.

World Value Survey, available at http://www.worldvaluessurvey.org/. 